IZA DP No. 5333

What Drives the Demand for Temporary Agency Workers?

Elke J. Jahn

Jan Bentzen

November 2010 


\title{
What Drives the Demand for Temporary Agency Workers?
}

\author{
Elke J. Jahn \\ Institute for Employment Research (IAB), \\ $A S B$, University of Aarhus and IZA \\ Jan Bentzen \\ ASB, University of Aarhus
}

Discussion Paper No. 5333

November 2010

IZA

P.O. Box 7240

53072 Bonn

Germany

Phone: +49-228-3894-0

Fax: +49-228-3894-180

E-mail: iza@iza.org

Any opinions expressed here are those of the author(s) and not those of IZA. Research published in this series may include views on policy, but the institute itself takes no institutional policy positions.

The Institute for the Study of Labor (IZA) in Bonn is a local and virtual international research center and a place of communication between science, politics and business. IZA is an independent nonprofit organization supported by Deutsche Post Foundation. The center is associated with the University of Bonn and offers a stimulating research environment through its international network, workshops and conferences, data service, project support, research visits and doctoral program. IZA engages in (i) original and internationally competitive research in all fields of labor economics, (ii) development of policy concepts, and (iii) dissemination of research results and concepts to the interested public.

IZA Discussion Papers often represent preliminary work and are circulated to encourage discussion. Citation of such a paper should account for its provisional character. A revised version may be available directly from the author. 
IZA Discussion Paper No. 5333

November 2010

\begin{abstract}
What Drives the Demand for Temporary Agency Workers?

Temporary agency employment has grown steadily in most European countries over the past three decades as part of the general trend towards increased employment flexibility. Yet to this day, it remains an open question what drives the demand for temporary agency workers. The paper examines, first, whether the deregulation of temporary agency employment is responsible for the growth of the flexible staffing industry. Second, we investigate the cyclical behavior of temporary agency employment. Using monthly data for Germany covering the period 1973-2008, we show that the continuous liberalization of this sector is not responsible for the surge in temporary agency employment. Our analysis reveals, moreover, that temporary agency employment exhibits strong cyclical behavior and correlates with main economic indicators in real time. Since most European countries promoted the use of temporary agency employment in a similar way, we believe that our results may be interesting from an international perspective as well.
\end{abstract}

JEL Classification: $\quad \mathrm{C} 41, \mathrm{~J} 23, \mathrm{J40}, \mathrm{J48}, \mathrm{K} 31$

Keywords: temporary agency employment, regulation, labor law, business cycle

Corresponding author:

Elke J. Jahn

Institut für Arbeitsmarkt- und Berufsforschung (IAB)

Regensburger Straße 104

90478 Nürnberg

Germany

E-mail: Elke.Jahn@iab.de 


\section{Introduction}

Germany has experienced substantial growth in the temporary help industry. Since the 1970s, the sector has grown on average 10 percent per year. By 2008, it employed nearly three percent of the wage and salary workforce. Most of this rise occurred during a period of increasing mass unemployment. Although temporary agency employment still accounts for a relative small share of paid employment, it plays an important role in job creation: one out of four new jobs in 2006 was created in this sector (Jahn 2010).

Yet Germany is not the only country that has witnessed an impressive rise in temporary agency employment. ${ }^{1}$ Temporary agency employment has doubled in most industrialized countries during the past decade. While the sector employed about one percent of the EU workforce at the end of the 1990s, it employed about two percent in 2008 (CIETT 2010). This process has made Germany, along with the UK and the Netherlands, one of the biggest markets for temporary help services in Europe. What factors drive the demand for temporary agency employment?

It is the aim of this paper to investigate two factors that might affect the demand for agency workers. First, the increased use of agency employment may have been driven by the widespread deregulation of the temporary help service sector at the end of the 1980s, when provisions for regular or permanent contracts were left essentially unaltered (e.g., De GraafZijl and Berkhout 2007, Storrie 2002, OECD 2004). Germany is an interesting country to analyze in this respect, since it has liberalized the law on agency employment extensively - in total six times. This process enables us to investigate whether the gradual deregulation affected the demand for temporary agency workers. Since most European countries promoted the use of temporary agency employment in a similar way, we believe that our results may be interesting from an international perspective as well.

1 To ease readability, we use the terms "temp jobs" and "agency work" interchangeably with temporary agency employment. 
There are numerous reasons why firms use temps. The literature has identified several key motives: to temporarily replace permanent staff who are on sick leave, to avoid firing costs in countries with strict employment protection legislation, to cut costs through the use of temp workers, who can be paid lower wages than direct-hire employees, to gain flexibility, or to adjust the size of the workforce to the volatility of the business cycle (e.g., Abraham 1990, Autor 2003; Houseman et al. 2003, Heinrich et al. 2009). To this day it remains an open question whether the growth of agency employment is strongly linked to the business cycle. This issue has taken on new importance during the recent crisis, since data on the main economic indicators, for example, production indices and real GDP, are usually released with a time lag of at least one quarter. The number of temporary agency workers, however, could in principle be reported in a timelier manner. Moreover, if agency employment is closely related to the business cycle or even a leading indicator, the advantage of this indicator would be that it is readily available and easy to understand (e.g., Canoy et al. 2008, De Groot et al. 2005). Temporary agency employment is argued to have a predictive value for the state of the economy because user firms react immediately to changes in product demand by releasing or hiring agency workers. However, in an economic upturn, the labor supply side might ration the demand for agency workers. If this is the case, agency employment might not show pronounced cyclical behavior. In order to shed light in this issue, we investigate, second, the cyclical behavior of temporary agency employment.

There are only a few studies analyzing the cyclical behavior of agency employment. Up to now, all available studies concentrate on the Dutch labor market. De Groot and Franses (2005) find that temporary agency employment and GDP correlate with agency employment in real time for the period 1977-2003. Using a composite indicator for the business cycle, these results were confirmed by Den Reijer (2006). The drawback of both studies is that they 
had to use the number of temp workers employed at Randstad ${ }^{2}$ on a quarterly basis, since the number of agency workers is only available on a yearly basis in the Netherlands. De GraafZilj and Berkhout (2007) show, for the period 1969-2002, that the demand for agency employment precedes Dutch GDP growth. However, their result is based on annual data and on a two-variable VAR model. Therefore, the results should be interpreted with care.

Boockmann and Hagen (2001) provide indications that agency employment in Germany follows a moderately cyclical pattern. They show that the probability of using agency workers increases if firms face an unexpected demand shock, while firms adjust their labor force to expected demand shocks by hiring workers on fixed-term contracts. However, their observation period (1994-1998) does not even cover a full business cycle and is based on yearly interviews of firms. Therefore, their finding might be considered very preliminary.

Regarding the effects of legislation on the demand of agency workers, there is only one study available. Antoni and Jahn (2009) provide evidence on how Germany's liberalization of agency work affected the employment duration of temps with the agency over the period 1980-2004. They find that the prolongation of the maximum assignment period significantly increased average employment duration, while all further liberalizations have reduced the employment tenure of temps.

If agency employment is considered to be a "flexible" part of the total workforce, higher frequency data than annual data are needed for a time series analysis. Moreover, GDP as a measure of production may seem to be a too general, aggregate variable. Instead of GDP as the main business cycle indicator, this study uses an industrial production index and the number of unemployed workers at monthly frequencies to investigate the relation between temporary agency employment and the business cycle and the effects of the deregulation of the law covering the temporary agency sector.

2 Randstad is the temporary work agency with the biggest market share in the Netherlands. 
The paper is organized as follows. The next section discusses how the business cycle affects the demand for agency workers. Section 3 describes the regulatory framework in which temporary work agencies operate in Germany. Section 4 presents the data. The estimation results are presented in Section 5. Section 6 summarizes and concludes.

\section{Temporary Agency Employment over the Business Cycle}

The central idea of temporary agency employment is to provide increased flexibility to the user firm that is "leasing" the worker. By falling back on temps, firms are able to adapt the size of their workforce to fluctuations in product demand. The superiority of temporary help employment derives from the agencies' role as matching intermediaries, improving matching quality and enabling quick personnel adjustments (e.g., Autor 2003, Houseman 2001, Mitlacher 1997, Neugart and Storrie 2006). User firms can return temps to the agencies as soon as they become redundant. Labor as a production factor loses its quasi-fixed character and becomes a variable cost factor for the leasing company (Oi 1962).

According to this argument, in an upswing, user firms adjust the size of their workforce to an increase in product demand by falling back on temps at first. If the higher product demand remains stable and the labor market tightens, firms begin to replace agency workers with permanent staff. In a downturn, when output demand falls, firms first dismiss temps before starting to lay off their permanent staff. As a consequence, agency work should have a strong cyclical component and may be a leading business cycle indicator.

The demand for temporary agency workers may also depend on the regulation of the temporary help sector itself. Liberalization decreases the quasi-fixed costs of labor in terms of either hiring or firing costs, and therefore has the same effect as decreasing employment protection legislation for a subset of the population. Saint-Paul (1996) models a two-tier labor market where only insiders with permanent contracts are protected by employment protection legislation, and where firms can dismiss workers on temporary (agency) contracts at no cost. 
The model predicts that asymmetric reforms that relax regulations only for the subset of the flexible working population should increase demand for the flexible workforce over the business cycle. This effect is, of course, particular pronounced in countries with strict employment protection legislation like Germany, where the majority of the working population enjoys strong employment protection, while the small segment of marginal workers remain vulnerable to dismissal decisions by firms.

However, there are at least three forces that might dampen the cyclical demand for agency workers. First, in all European countries, temps usually express a desire for regular openended jobs (CIETT 2002). In an upswing, the probability of finding a regular job increases, and workers tend to leave the temp sector to take permanent jobs (e.g., Abraham 1990, Autor 2001, Burda and Kvasnicka 2006). If the labor market then tightens, temporary work agencies are left with low-skilled workers or with workers who prefer flexible working conditions (Houseman et al. 2003). Consequently, in a boom, it is likely that the labor supply will ration labor demand, at least in the segment of skilled and qualified temporary agency work.

Second, how firms react to output fluctuations also depends on the relative costs of alternative adjustment instruments. Apart from hiring temp workers or workers on fixed-term contracts, firms can also use internal adjustment instruments like overtime, flexible working hours, and a short-term increase in labor productivity. An essential factor determining the relative costs of the adjustment instruments is, again, the overall labor regulation. For example, the use of overtime as an alternative flexibility strategy depends on the capabilities of the existing workforce, the qualifications required, and last but not least, the overtime premium itself. Consequently, if there are alternative adjustment instruments available that are less costly than agency employment might even lag the business cycle.

Third, the main regulations affecting the demand for flexible workers in most European Countries are upper limits on the period for assigning temps to a single user firm, restrictions on the number of renewals of an employment contract with a particular agency, and upper 
limits on the cumulative duration of temporary employment contracts. Such regulations usually set upper limits on the duration of an assignment to the user firm. In case of a longerlasting upturn, temp workers will be less suited to serve as a buffer. Therefore countries with strong regulation of the temp sector, like Germany until 2004, should not display a strong cyclical pattern.

\section{Legal Framework}

Changing labor law regulations can lead to changes in the use of agency workers. In Germany, temporary agency employment is regulated by national legal statutes. The Labor Placement Act governs this sector, with specific regulations applying only to temporary help agencies. Since the Labor Placement Act came into effect in 1972, it has been amended several times (see Table 1). These reforms were mainly designed to increase the flexibility of the user firms.

Unlike most countries, Germany initially permitted agency employment only on the basis of a permanent employment contract with the temp agency. In order to prevent agencies from circumventing the principle of an open-ended contract, the re-employment ban and the synchronization ban were included in the legislation. The re-employment ban only permitted one-time termination and re-employment. The synchronization ban required that an employment contract with a temp exceed the length of the first assignment by at least 25 percent. The maximum period of assignment was initially limited to three months. In 1982, the use of temps in the construction sector was prohibited.

[Table 1 about here]

The subsequent three reforms in 1985, 1994, and 1997 gradually increased the maximum period of assignment to a user firm from 3 to 12 months. In addition, the reform in 1997 permitted a one-time synchronization of the employment contract with the agency and the first assignment; from this year on, agencies were allowed to conclude fixed-term contracts 
with their workers. The reform of 2002 extended the maximum period of assignment up to two years. Moreover, it stated that temp workers have the right to the same remuneration as workers employed directly by the user firm after working there for more than 12 months.

The most marked change in the legislation was the recent reform of 2004. This reform was intended to increase the remuneration of the agency workers by stipulating equal pay from the first day of an assignment on. The new law allows deviation from the principle of equal treatment if the agency applies the conditions stipulated in a sectoral collective agreement to all its temp workers. In addition, by signing a collective agreement, the agency can free itself from all other regulations. As a consequence, numerous collective agreements were concluded in anticipation of this reform. By the end of 2003, nearly 97 percent of all temporary help agencies paid their temps according to a sectoral collective agreement. Consequently, the principle of equal treatment and all other regulations have lost any practical meaning for the temporary help industry.

\section{Data and Descriptive Analysis}

In Germany, temporary work agencies are obliged to report the monthly stock of temps on assignment to user firms to the Federal Employment Agency's "Labor Placement Statistics" twice a year. The advantage of the Labor Placement Statistics for our purposes is that the total number of temps is available on a monthly basis from January 1973 on. In late 2008, in reaction to the economic crisis and to avoid mass layoffs, the German government began subsidizing short-term work on a large scale. To avoid any distorting effects, we therefore decided to use data only up to June 2008.

Nevertheless, the Labor Placement Statistics have one disadvantage: as a consequence of German reunification and the reorganization of the Public Employment Service, the stock of temps refers to West Germany before 1993. Since January 1993, information on the stock of temps is only available for unified Germany. Since temporary agency employment was 
nonexistent in East Germany before the fall of the Berlin Wall, we do not expect that this structural break will affect our results.

According to the Labor Placement Statistics, the number of agency workers increased from 28,000 in 1973 to about 794,000 in June 2008. The labor market flows suggest that the temporary help industry is even larger than any stock figure, and larger than the industry's share of total employment would suggest. In 2008, about 1,050,000 new temporary agency jobs were created and 1,170,000 terminated.

Temporary agency employment grew on average about 10 percent per year during the observation period; in 2008, temporary help workers constituted three percent of the total dependent workforce and two percent of the overall workforce. Most temps are male, which is true for our entire observation period. The share of temporary agency workers being unemployed directly before they entered into the sector increased markedly from 29 percent between 1973 and 1981 to 60 percent during the period 2003 to 2008. More than two-thirds of all temps are employed in manufacturing, as laborers or in technical occupations. This pattern has been stable since 1973 (Jahn 2010).

Despite the rather strict regulation of the sector, agency jobs are spot market jobs that provide low remuneration and employment protection for the majority of the workers. Only workers with job tenure over six months are covered by employment protection legislation. During 1980-2004, only about 20 to 30 percent of agency workers were employed at the same agency more than six months (Antoni and Jahn, 2009). Consequently, only a small share of the temps was protected against unfair dismissals. Agency workers have to accept an average wage differential of about 20 percent (Jahn 2010). This wages disadvantage makes it likely that agency workers will leave the sector as soon as they find a better-paid job.

In order to investigate the cyclical behavior of agency work and to test whether agency employment is used as an adjustment instrument to changing demand conditions, we use the following indicators: first, since about two-thirds of all temps work in the manufacturing 
sector, we use the real growth rate of industrial production (volume index) instead of the GDP growth rate. Since the share of temps who were unemployed before accepting a temp job increased during our observation period, we use the number of unemployed persons as a second indicator. Compared to the number of employed people, this may be a more adequate measure for the business cycle, since we cannot exclude the possibility that temp workers substitute permanent employees. All time series variables are for West Germany up to end of 1992, and afterwards for unified Germany ${ }^{3}$.

Due to German unification and the fact that macroeconomic variables are often found to exhibit non-stationary behavior, we use the log of the first differences of the variables. Finally, since high-frequency data contain some short-run noise, a centered, twelve-period moving-average filter has been applied to the time series before differencing the data. ${ }^{4}$

[Figure 1 and 2 about here]

An initial visual inspection of Figures 1 and 2, which display the growth rate of agency employment along with our two business cycle indicators, confirms a clear procyclical pattern. Moreover, it is hard to identify any structural breaks in the time series data, except for the year 1982, when temporary agency employment was banned in the construction sector.

\section{Structural Breaks and Cyclical Behavior}

Did the reforms of the law covering the temporary help sector affect the demand for temps? As pointed out in Section 3, with the exception of the reform of 1982, which prohibited agency work in the construction sector, all reforms were designed to increase flexibility for user firms. Consequently, we would have expected that all reforms after 1982 would have

3 Both variables are provided by the Deutsche Bundesbank and are accessed via Datastream. Moreover, despite extensive research, we could only find the yearly GDP growth rate divided into West and East Germany for this long time span. We would have lost information by using the GDP growth rate since we had to use the overall annual data. Furthermore, the number of employed workers is only available on a monthly basis from 1991 on.

4 Note that the moving average filter is "smoothing" the series more than just seasonally adjusting the data by $\mathrm{X} 11$, and thus the smoothed time series depicts the procyclicality of agency employment more clearly. 
increased the demand for temps. The reforms of 1997 and 2004 were particularly farreaching, and the effects should be pronounced.

As first steps, we analyzed the monthly data using ARIMA models, including dummybreaks and intervention variables as well as Chow tests for breaks in intercepts and/or trends. We included seasonal adjustments by X11 and detrended the data using a Hodrick-Prescott filter. Despite these efforts, we could not identify any relation between the time of the reforms and the demand for temps.

However, some sub-periods proved to be characterized by a close to linear development, and we therefore applied the Bai-Perron (2003) test for structural breaks. The advantage of the Bai-Perron test is that it allows for breaks at unknown dates in the intercept and trend. The Bayesian Information Criteria (BIC) selects seven breaks, which are shown in Figure 3. However, with the exception of the 1982 reform, these break points are small and not strongly related to the reforms of the Labor Placement Act. The break point in 4/1994 is closely related to the reform of January 1994 and the break point in 11/2001 could be related to the reform that took place in January 2002. However, the latter break point indicated that the demand has decreased, which is not in accordance with our expectation. To sum up, it seems that the deregulation of the sector is not responsible for the growth in agency employment in Germany since the 1970 s.

In order to examine whether temporary agency employment is a leading economic indicator, we perform bivariate Granger causality tests. As the level values are found to be non-stationary, we use first-differenced values. If the industrial production index (number of unemployed) explains the number of temps and if reversing the variables in the regression reveals that agency employment does not influence industrial production (unemployment), a hypothesis of Granger causality from industrial production (unemployment) to agency work cannot be excluded. 
We run the causality test for the full sample and separately for the pre- and post-unification periods. An $F$-test is used to ascertain whether lags of the industrial production index significantly help to explain the number of agency workers and vice versa. We perform a similar set of tests for our second business cycle indicator, representing the number of unemployed people.

Furthermore, the Geweke, Meese, and Dent causality test is used, which is based on the same $\mathrm{H}_{0}$-hypothesis as the Granger test but performed by testing leads instead of lags. The number of lags included has been decided based on the Akaike information criterion (AIC) and the Schwartz criterion (SC): we selected a lag level of eight months by minimizing the values of these information criteria.

Table 2 presents the results for the two sets of Granger causality tests, where the variables were first seasonally corrected by using the X11 procedure. For the entire sample period, industrial production Granger-causes agency employment and vice versa, which might suggest a strong cyclical movement. For the post-unification period, both tests suggest that causation runs from industrial production to agency employment when requiring at least a 5 percent level of significance. This result is not in accordance with the expectation that agency employment is a leading economic indicator. For our second indicator, the number of unemployed, there seems to be some bi-directional causality and, with some variation, also with respect to the second sub-period.

[Table 2 about here]

The Granger test is designed to handle pairs of variables, and may produce misleading results when the true relationship involves more variables. We therefore estimate a threevariable VAR. In this case, possible directions of causality can be tested by including all 
variables simultaneously. ${ }^{5}$ All variables in the VAR model are treated symmetrically by including an equation for each variable explaining its evolution based on its own lags and the lags of all the other variables. In our case, the variables agency employment, industrial production, and unemployment have been selected. We expect, first, that the demand for temps is positively influenced by real production, and second that temporary employment may fall if the level of unemployment is low. The reason for the latter expectation is that in this case, labor supply may ration labor demand. The VAR can be written in a compact form as:

$$
X_{t}=A_{0}+A_{1} X_{t-1}+\ldots+A_{p} X_{t-p}+\varepsilon_{t}
$$

The $3 \times 1$ vector $X_{t}$ represents first-difference log values of our three variables. In order to find the appropriate lag length, the model is tested down, beginning with lag length of order twelve (months), and subsequently stepwise reducing to the order to six months. A multivariate generalization of the AIC and the SC tests is applied as a test statistic for lag length. Moreover, a likelihood ratio (LR) test is used to decide upon the number of lags included in the VAR model, since the AIC/SC criteria in some cases indicate a very short lag structure. In most cases, a lag level of 6 seems most appropriate when taking into consideration both the AIC/SC criteria and the LR test. Table 3 reports the causality test values when all variables are included simultaneously in the VAR model.

[Table 3 about here]

For the whole sample period, Table 3 indicates bi-directional Granger causality between agency employment and industrial production and between agency employment and unemployment. The sign of the total impact from all parameter estimates in the VAR model is

5 Since the question of causality is included in the present analysis and since the parameters in the VAR model are not significant and robust, we do not undertake an impulse response function analysis in the following. 
reported in brackets. The results show that increases in industrial production imply increasing temporary agency employment, but the reverse relation is significant as well. In some cases, the impact is close to zero, indicated by a " 0 " in brackets, although statistically, the parameter estimates are found to be significant. For the second sub-period, these results are partly confirmed. These results correspond to the graphs in Figures 1 and 2, where the crosscorrelations between the respective variables attain the highest values at lag zero, i.e., the comovements take place more or less simultaneously between the respective variables.

To investigate whether our results are robust, we used the number of employed workers and the Ifo climate index instead of the industrial production index. Since both variables are only available on a monthly basis from 1991 on, we only investigated the relationship for our second sub-period. Table 4 presents the results for the Granger Causality test. While total employment does not cause agency employment and vice versa, we found a relationship between the Ifo climate index and temporary agency employment, again indicating that temporary agency employment is at least not a leading indicator.

\section{[Table 4 about here]}

As further robustness checks we used the DAX and the real growth rate of GDP instead of the industry production index. ${ }^{6}$ We also ran the estimations only for temps who were employed in the manufacturing sector. Finally, since laborers, who are likely assigned more often on a daily basis, are part of the manufacturing sector, we performed the analysis separately for laborers and the remaining workers in the manufacturing sector. It turns out that our results remain mainly the same.

\footnotetext{
6 Note that for our observation period the growth rate of the GDP is only available on a yearly basis.
} 


\section{Summary and Conclusion}

A commonly accepted theory is that the increase in temporary agency employment in most European countries is merely a consequence of the widespread lifting of regulations governing this sector. We tested this hypothesis using longitudinal data on temporary agency employment for Germany, which reformed its regulations six times since 1973, while leaving provisions for regular contracts in place. Our analysis showed that the deregulation of the law was not responsible for the increased demand for agency workers.

Second, the paper has shown that the demand for agency workers is highly procyclical. Changes in the state of the economy seem to run parallel with changes in the demand for agency workers. Moreover, we could not find evidence supporting the view that agency employment is a leading economic indicator. However, as Canoy et al. (2009) point out, this finding does not disqualify temporary agency employment as a leading indicator. Countries that release the number of agency workers faster and more frequently than traditional economic indicators will still be able to predict the state of the economy in a timelier and more accurate manner.

The increase in the demand for agency employment, together with its strong procyclical pattern, might be treated as evidence that user firms are making increased use of flexible staff to adjust to unexpected shocks or business cycle conditions. This might be especially the case in countries like Germany, where temps are predominantly found in the production sector one where international competition is fierce.

In Germany, every time the regulation of temporary agency employment is about to be changed, heated and prolonged battles take place between interest groups, the labor parties, and politicians. It usually takes a great deal of time and tremendous bargaining effort before the parties finally agree on what are often very marginal reforms. The same holds at the European level. At the end of 2008, the European Parliament approved a proposal for a directive on agency employment after nearly 20 years of bargaining. Our results call into 
question such substantial investments of time and resources, since the market does not seem

to react strongly to these reforms.

\section{References}

Abraham, Katharine G. 1990. "Restructuring the employment relationship: The growth of market-mediated work arrangements." In Katharine G. Abraham and Robert B. McKersie, eds., New developments in the labour market: Toward a new institutional Paradigm. Cambridge, MA, MIT Press, pp. 85-119.

Antoni, Manfred and Elke J. Jahn. 2009. "Do changes in regulation affect employment duration in temporary HELP agencies.?" International Labor Relations Review 62(2), pp. $226-251$.

Autor, David. 2001. "Why do temporary help firms provide free general skills training?" Quarterly Journal of Economics 116(4), pp. 1409-1448.

Bai, Jushan and Pierre Perron. 2003. "Computation and Analysis of Multiple Structural Change Models.” Journal of Applied Econometrics 18(1), pp. 1-22.

Boockmann, Bernhard and Tobias Hagen. 2001. "The Use of Flexible Working Contracts in West Germany: Evidence from an Establishment Panel", ZEW Discussion Paper No. 0133, Mannheim.

Burda, Michael and Michael Kvasnicka. 2006. „Zeitarbeit in Deutschland: Trends und Perspektiven,“ Perspektiven der Wirtschaftspolitik 7(2), pp. 195-225.

Canoy, Marcel, Peter Donker van Heel and Erwin Hazebroek, E. (2009) “Temporary Agency Work as a leading economic indicator" ECORYS Netherlands.

CIETT. 2002. "Rationale of Agency Work - European Labour Suppliers and Demanders' Motives to Engage in Agency Work", Rotterdam.

CIETT. 2010. Data and Statistics on Temporary Agency Work, Ciett statistics 2006, http://www.ciett.org/fileadmin/templates/ciett/docs/CIETT_2006_Statistics.pdf.

De Graaf-Zijl, Marloes and Ernest E. Berkhout. 2007. "Temporary agency work and the business cycle.” Journal of International Manpower 28 (7), pp. 539-556.

De Groot, Bert, and Philip Hans Franses. 2005. "Real time estimates of GDP growth." Econometric Institute Report 2005-01, Erasmus University Rotterdam.

Den Rejer, A. (2006), The Dutch business cycle: which indicators should we monitor? De Nederlandsche Bank, Amsterdam.

Heinrich, Carolyn J., Peter R. Mueser, and Kenneth R. Troske. 2009. "The Role of Temporary Help Employment in Low-wage Worker Advancement." In David Autor, ed., Labor Market Intermediation, Chicago: The University of Chicago Press, forthcoming.

Houseman, Susan N. 2001. "Why Employers Use Flexible Staffing Arrangements: Evidence from Establishment Survey,” Industrial and Labor Relations Review 55, 149-170.

Houseman, Susan N., Arne J. Kalleberg, and George A. Erickcek. 2003. "The Role of Temporary Help Employment in Tight Labor Markets." Industrial and Labor Relations Review 57(1), pp. 105-127.

Jahn, Elke J. 2010. "Reassessing the Wage Penalty for Temps in Germany," Journal of Economics and Statistic 230 (2), pp. 208-233. 
Mitlacher, Lars W. 2007. "The Role of Temporary Agency Work in Different Industrial Relations Systems - a Comparison between Germany and the USA.” British Journal of Industrial Relations 45(3), pp. 581-606.

Neugart, Michael and Donald Storrie. 2006. "The Emergence of temporary work agencies." Oxford Economic Papers 58(1), pp. 137-156.

OECD. 2004. "Employment Outlook," Paris: OECD.

Oi, Walter. 1962. "Labor as a Quasi-Fixed Factor.” Journal of Political Economy 70(6), pp. 538-555.

Saint-Paul, Gilles. 1996. Dual Labor Markets, A Macroeconomic Perspective, Cambridge Mass, MIT Press.

Storrie, Donald. 2002. "Temporary agency work in the European Union." European Foundation for the Improvement of Living and Working Conditions: Dublin. 


\section{Tables and Figures}

Table 1: Major reforms of the labor placement act

\begin{tabular}{|c|c|}
\hline Period & Regulation \\
\hline Aug 7, 1972 & Temporary agency employment was allowed \\
\hline starting Jan 1, 1982 & Prohibition of temporary agency employment in the construction sector \\
\hline starting May 1, 1985 & Extension of the maximum period of assignment ( 3 to 6 months) \\
\hline starting Jan 1, 1994 & Extension of the maximum period of assignment ( 6 to 9 months) \\
\hline $\begin{array}{l}\text { starting April } 1, \\
1997\end{array}$ & $\begin{array}{l}\text { Extension of the maximum period of assignment ( } 9 \text { to } 12 \text { months), } \\
\text { Permission of one-time synchronization of employment contract and first assignment } \\
\text { Permission to conclude fixed-term contracts (max. } 3 \text { prolongations) }\end{array}$ \\
\hline starting Jan 1, 2002 & $\begin{array}{l}\text { Extension of the maximum period of assignment ( } 12 \text { to } 24 \text { months), } \\
\text { Principle of equal treatment after } 12 \text { months }\end{array}$ \\
\hline starting Jan 1, 2004 & $\begin{array}{l}\text { Principle of equal treatment } \\
\text { Elimination of the maximum period of assignment } \\
\text { Elimination of the synchronization and re-employment ban } \\
\text { Exception of the principal of equal treatment if the agency applies a collective agreement }\end{array}$ \\
\hline
\end{tabular}

Source: Antoni and Jahn (2009)

Figure 1: Temporary agency employment and industrial production

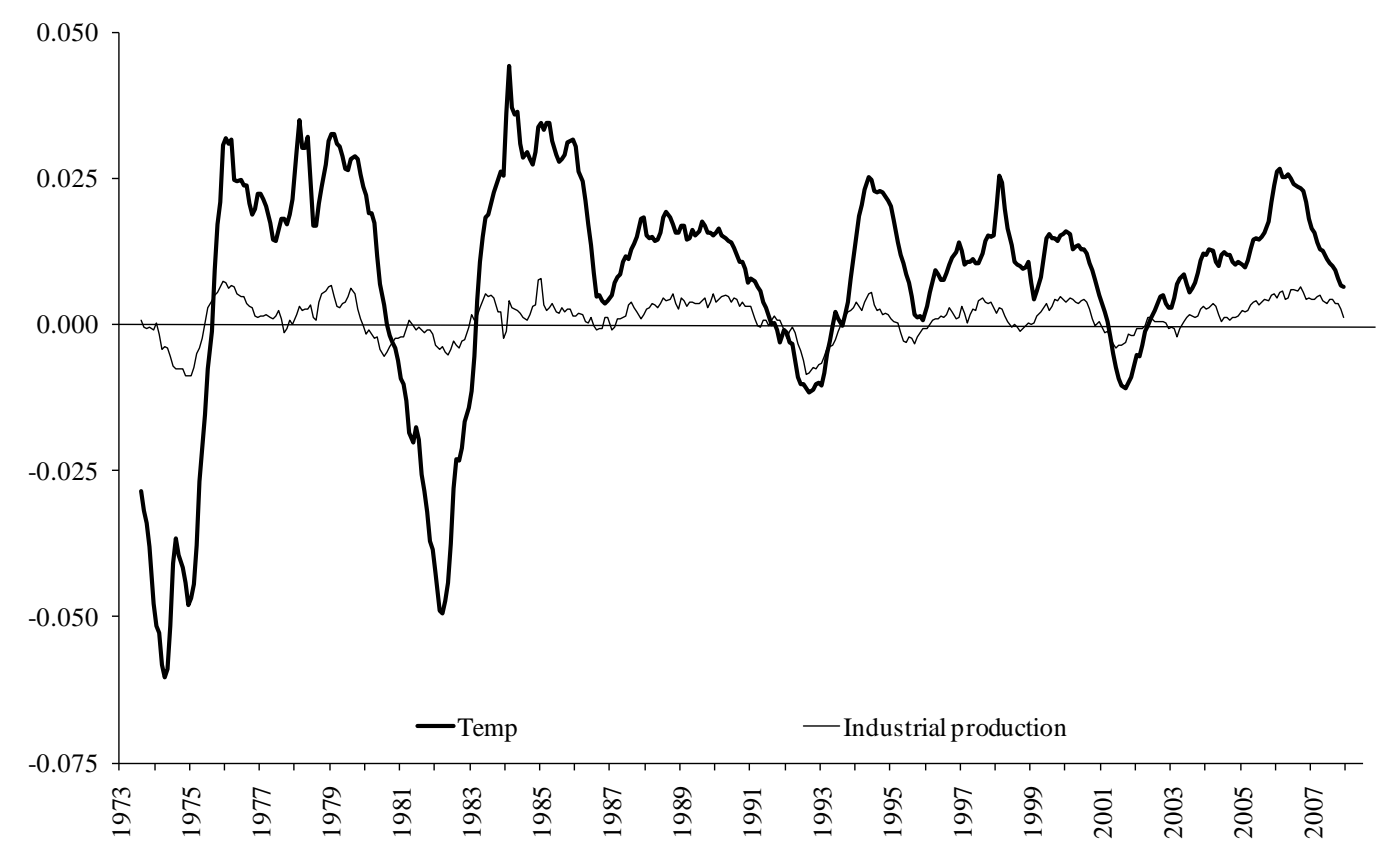

Notes: The level values of the variables are smoothed by a 12-period centered moving average; first differences of $\log$ values are displayed at the vertical axis.

Sources: Datastream (Variable: BDIPTOT.G) and Labor Placement Statistics 
Figure 2: Temporary agency employment and unemployment

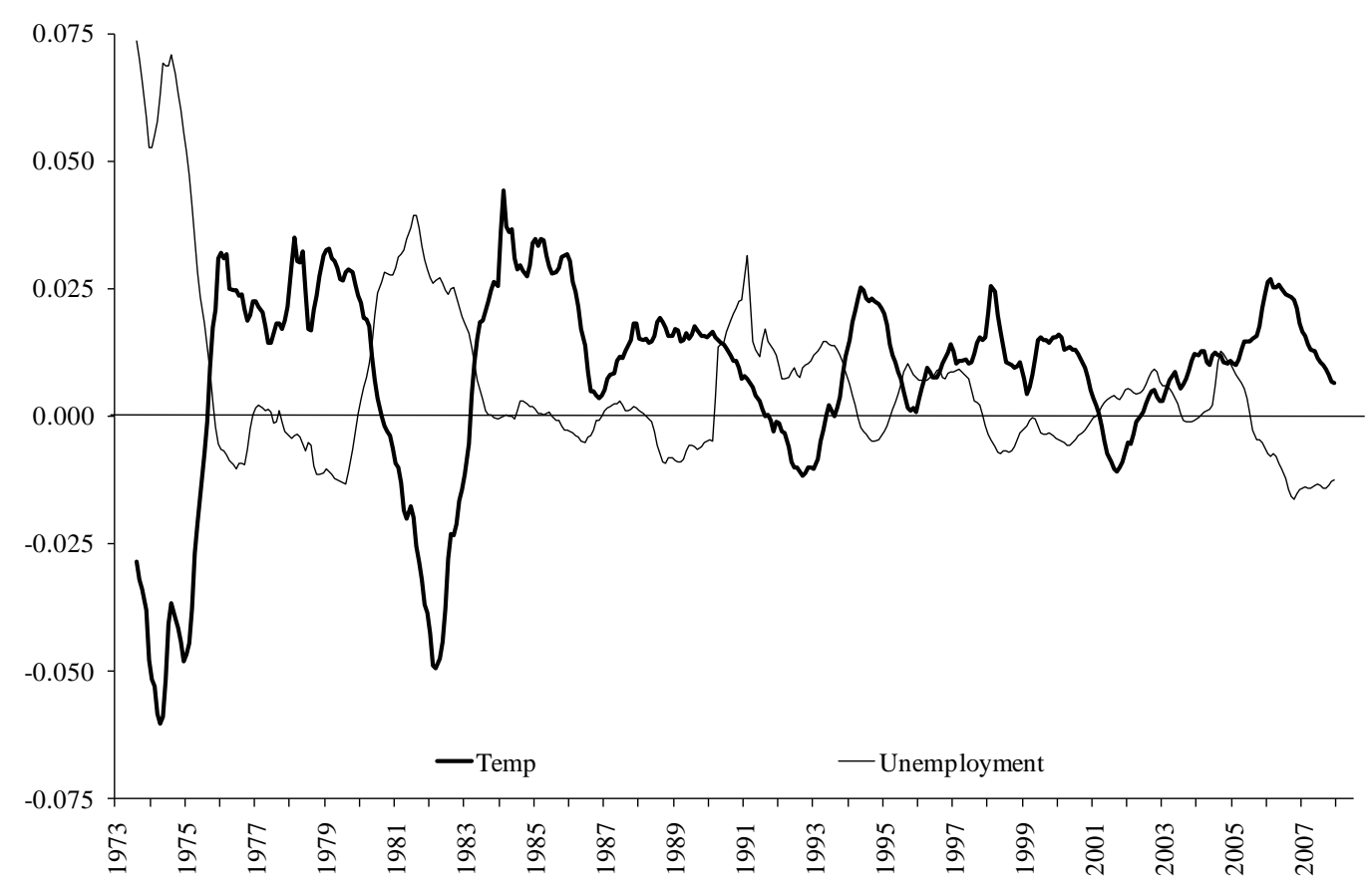

Notes: The level values of the variables are smoothed by a 12-period centered moving average; first differences of log values are displayed at the vertical axis.

Source: Datastream (Variable: BDUNPTOTP) and Labor Placement Statistics

Figure 3: Temporary agency workers, 1973-2008 (log values)

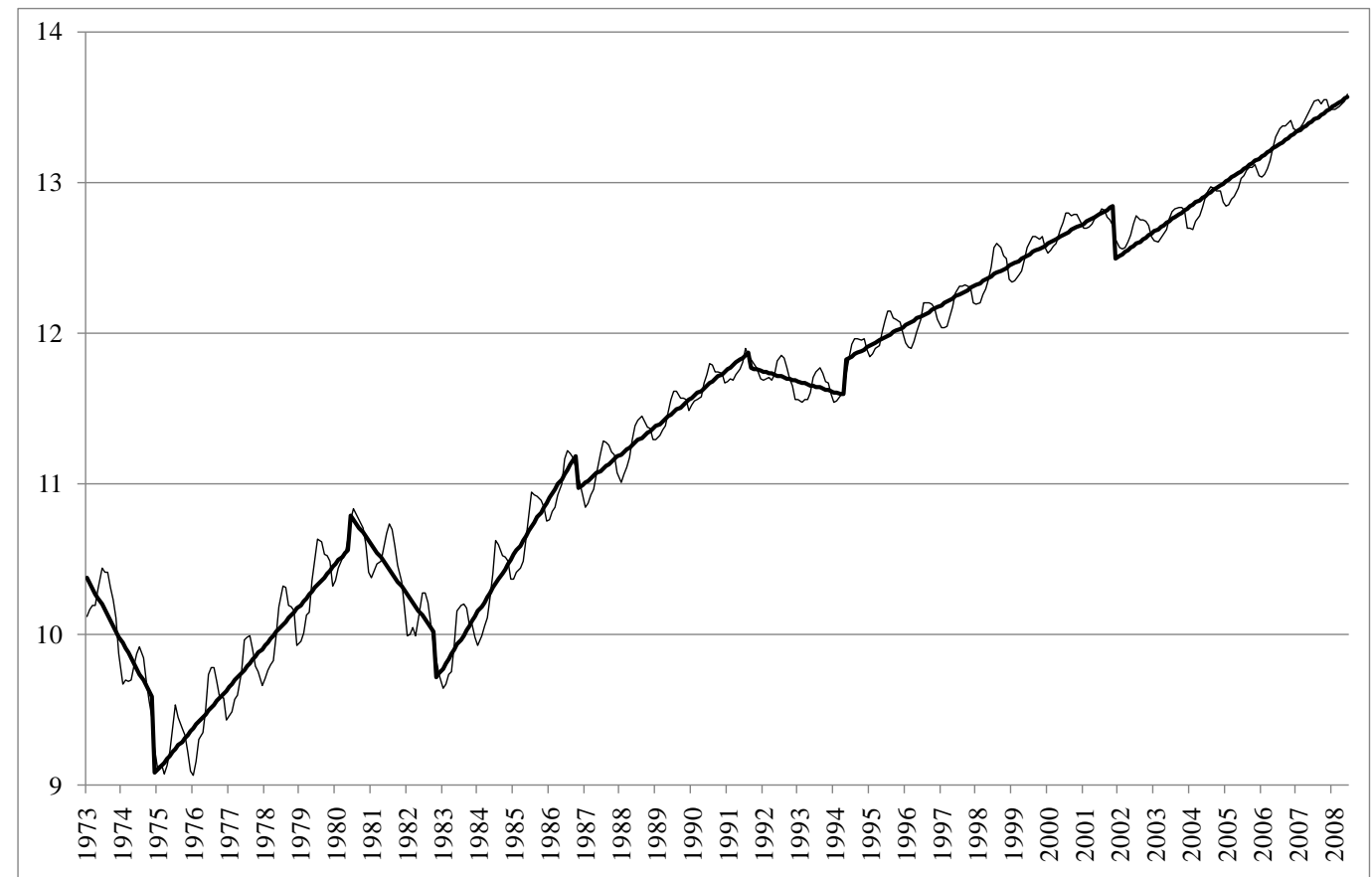

Notes: The linear trend segments detecting by using a procedure for detecting structural breaks developed by Bai and Perron (2003). Allowing up to ten break points-with unknown break points - the BIC information criteria select seven breaks with the breaks as indicated in the graph. The break points are 1974:11, 1980:05, 1982:10, 1986:10, 1991:08, 1994:04 and 2001:11. 
Table 2: Pairwise causality tests, 1973-2008

\begin{tabular}{|c|c|c|c|c|c|c|}
\hline \multirow[b]{2}{*}{ Industrial Prod. $\rightarrow$ Temp } & \multicolumn{2}{|c|}{$\begin{array}{c}\text { 1973-2008 } \\
\text { Granger / GMD }\end{array}$} & \multicolumn{2}{|c|}{$\begin{array}{c}\text { 1973-1992 } \\
\text { Granger / GMD }\end{array}$} & \multicolumn{2}{|c|}{$\begin{array}{c}\text { 1993-2008 } \\
\text { Granger / GMD }\end{array}$} \\
\hline & $\begin{array}{r}2.33 * *[+] \\
(0.02)\end{array}$ & $\begin{array}{l}2.49 * * \\
(0.01)\end{array}$ & $\begin{array}{r}1.53 \\
(0.15)\end{array}$ & $\begin{array}{l}1.26 \\
(0.27)\end{array}$ & $\begin{array}{r}2.69 * *[+] \\
(0.01)\end{array}$ & $\begin{array}{l}2.34 * * \\
(0.02)\end{array}$ \\
\hline Temp $\rightarrow$ Industrial Prod. & $\begin{array}{r}3.08 * *[+] \\
(0.00)\end{array}$ & $\begin{array}{l}3.31 * * \\
(0.00)\end{array}$ & $\begin{array}{r}1.48 \\
(0.17)\end{array}$ & $\begin{array}{l}2.02 * * \\
(0.05)\end{array}$ & $\begin{array}{r}1.70 *[+] \\
(0.10)\end{array}$ & $\begin{array}{l}1.58 \\
(0.13)\end{array}$ \\
\hline Unemployment $\rightarrow$ Temp & $\begin{array}{r}3.37 * *[-] \\
(0.00)\end{array}$ & $\begin{array}{l}3.07 * * \\
(0.00)\end{array}$ & $\begin{array}{r}1.38 \\
(0.21)\end{array}$ & $\begin{array}{l}1.00 \\
(0.44)\end{array}$ & $\begin{array}{r}2.10 * *[-] \\
(0.04)\end{array}$ & $\begin{array}{l}1.61 \\
(0.13)\end{array}$ \\
\hline Temp $\rightarrow$ Unemployment & $\begin{array}{r}4.46^{* *}[-] \\
(0.00)\end{array}$ & $\begin{array}{l}2.38 * * \\
(0.02)\end{array}$ & $\begin{array}{r}1.49 \\
(0.16)\end{array}$ & $\begin{array}{l}1.83^{*} \\
(0.07)\end{array}$ & $\begin{array}{r}1.99 * *[-] \\
(0.05)\end{array}$ & $\begin{array}{l}1.87 * \\
(0.07)\end{array}$ \\
\hline
\end{tabular}

Notes: Log values of the variables measured in first differences are used, where the number of lags is eight, and a dummy included for 1992:12 due to German unification. $p$-values are reported in parentheses, * indicates significance at at least the 10 percent level, and $* *$ at least the 5 percent level.

Table 3: Causality tests in a three-variable VAR model, 1973-2008

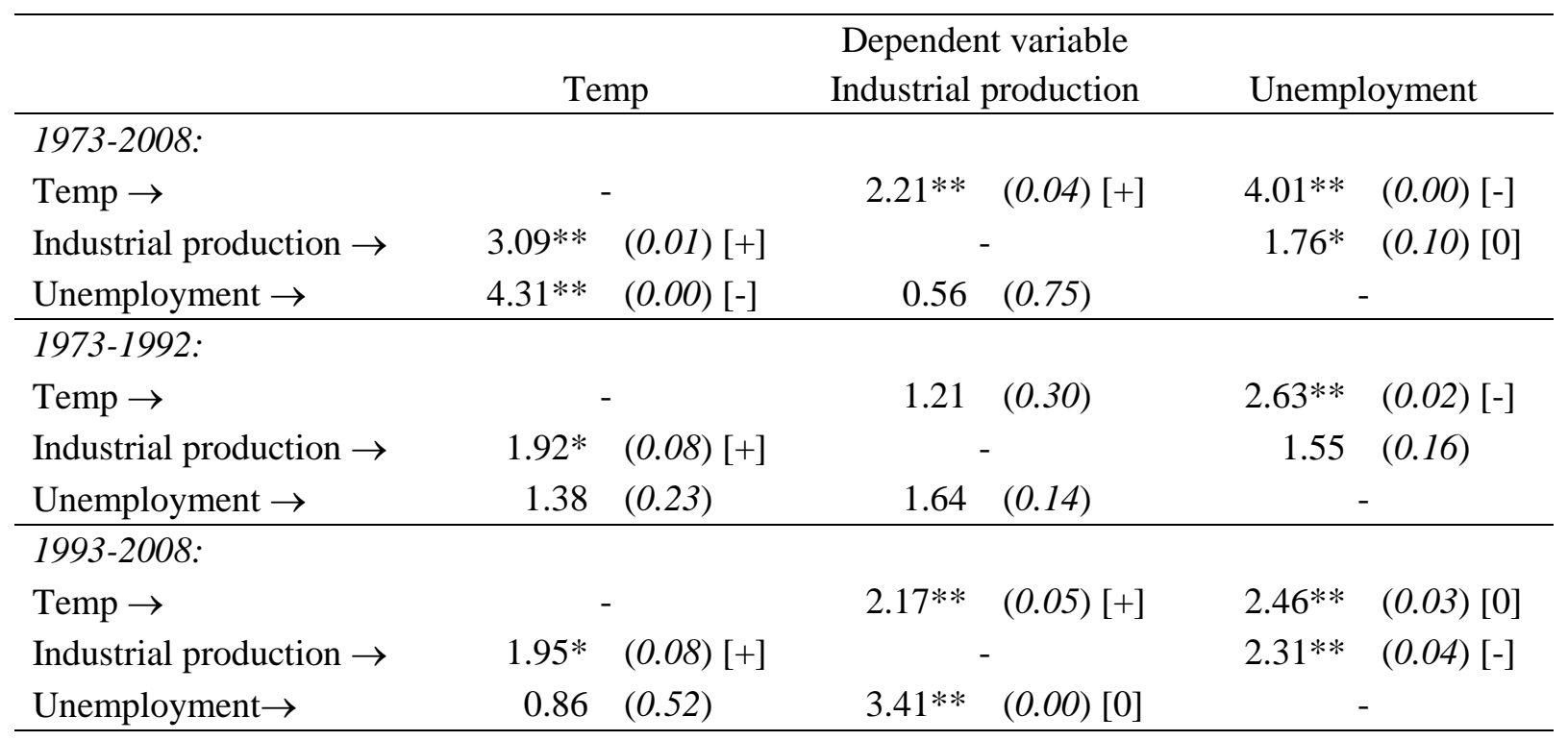

Notes: Log values of the variables measured in first differences are used in the tests, where the number of lags is initially set to ten. The final number of lags is chosen to be six as a compromise for all the three models, as the AIC/SBC information criteria indicates short lags and a likelihood ratio test concerning restricting the lag length selects longer lags. A dummy variable is included for 1992:12 due to unification. $p$-values are reported in parentheses, * indicates significance at at least the 10 percent level, and ** at least the 5 percent level. The sign in brackets indicates the direction of causality, based on the sign and values of the parameter estimates in the VAR. [0] indicates a close to zero impact between the variables, although the combined test in some cases indicates a significant relationship. 
Table 4: Pairwise causality tests, 1993-2008

\begin{tabular}{lrllrl}
\hline & Granger / GMD & & \multicolumn{2}{c}{ Granger / GMD } \\
\hline \multirow{2}{*}{ Employment $\rightarrow$ Temp } & 1.15 & 0.98 & Ifo climate $\rightarrow$ Temp & $4.04^{* *}[+]$ & $3.31^{* *}$ \\
& $(0.33)$ & $(0.45)$ & & $(0.00)$ & $(0.00)$ \\
Temp $\rightarrow$ Employment & $1.71 *[0]$ & 1.59 & Temp $\rightarrow$ Ifo climate & 1.11 & 1.17 \\
& $(0.10)$ & $(0.13)$ & & $(0.36)$ & $(0.32)$ \\
\hline
\end{tabular}

Notes: Log values of the variables measured in first differences are used, where the number of lags is $8 . p$ values are reported in parentheses, $*$ indicates significance at at least the 10 percent level, and $* *$ at least the 5 percent level. The sign in brackets indicates the direction of causality, based on the sign and values of the parameter estimates in the VAR. [0] indicates a close to zero impact between the variables, although the combined test in some cases indicates a significant relationship. 